\title{
Konsep al-Ta'ābudiyyah dan Kepentingannya dalam Hukum Islam Semasa
}

\author{
Wan Mohd Yusof Wan Chik \\ Universiti Sultan Zainal Abidin, wanyusof@unisza.edu.my \\ Abdul Karim Ali \\ Universiti Malaya, abdkarim@um.edu.my
}

\begin{abstract}
Abstrak
Makalah ini menjelaskan konsep al-ta'ābudiyyah dan kepentingannya dalam berinteraksi dan memahami isu-isu hukum Islam semasa. AlTa'äbudiyyah ialah hukum yang tidak dapat dikesan 'illah baginya. Ia satu elemen penting dalam ijtihad. Makalah ini cuba menjelaskan masalah salah faham terhadap konsep, peranan dan kedudukan alta'ābudiyyah dalam ijtihad. Untuk mencapai objektifnya, makalah ini menganalisis secara induktif dan deduktif maklumat-maklumat yang dikumpulkan melalui kajian perpustakaan. Makalah ini membuktikan bahawa konsep al-ta'ābudiyyah suatu perkara penting dalam usaha berinteraksi dan memahami isu-isu hukum Islam semasa, khususnya dalam menjaga ketegaran syariat Islam sepanjang zaman dari sudut pengukuhan konsep ibtila', pembuktian keterbatasan akal manusia, penetapan 'standard' kemaslahatan dan kepentingan proses ijtihad dalam mencapai matlamat pensyariatan.
\end{abstract}

Kata kunci: al-ta 'ābuddiyyah, ijtihad, hukum Islam semasa, maslahat

\section{The Concept of al-Ta'ābudiyyah and Its Importance in Contemporary Islamic Rulings}

\begin{abstract}
The article explains the concept of al-ta'ābudiyyah and its importance in understanding related issues of contemporary Islamic rulings. It is a set of rulings which is not able to derive its cause clearly. It is an important element in ijtihad. The article elaborates misunderstanding of the concept of al-ta'ābudiyyah, its role as well as its position in ijtihad. This article uses inductive and deductive analysis. It proves that the concept of al-ta'ābudiyyah is an important in dealing with contemporary Islamic rulings especially in protecting the evergreen of Shariah in term of strengthening of ibtilā', the limitedness of human reason, setting the standard of public interest and the importance of legal exercises in achieving the objectives of Shariah.
\end{abstract}


Keywords: al-ta'ābuddiyyah, ijtihad, contemporary Islamic rulings, mașlaḥah

\section{Pendahuluan}

Al-Ta 'äbudiyyah adalah satu perkataan yang sering ditemui dalam perbincangan ilmu usul fiqh dan maqasid syariah. Secara umumnya ia merujuk kepada hukum yang tidak dapat dikesan atau difahami rasionaliti disebalik pensyariatanya. Sebagai contoh jumlah rakaat solat, anggota wuduk, amalan-amalan tertentu dalam ibadat haji dan lain-lain. Justeru itu, kategori hukum hakam sebegini dianggap oleh sesetengah pihak sebagai menyalahi logik dan rasionaliti ijtihad. Sekaligus ia membatas potensi akal untuk berinteraksi dengan nas-nas syarak khususnya dalam menangani isu-isu hukum Islam semasa. Akibatnya, dalam banyak keadaan ia dijadikan sasaran oleh pelbagai aliran Islam terkini untuk menyerang kewibawaan hukum fiqh dan para mujtahid. Bahkan dalam beberapa keadaan yang ekstrem, nas yang menjadi sandaran turut dipertikaikan sama. Kecenderungan sebegini biasanya dirujuk kepada istilah-istilah seperti ta 'lìl, maslahat dan maqasid Shariah. Ia disokong dengan kewujudan sejumlah besar karyakarya kontemporari demi menggerakkan minda ijtihad dalam kalangan cendekiawan Islam. Diakui bahawa, persoalan ta 'ábudiyyah turut ditulis, namun peranannya dalam syariat Islam kurang digarap secara terperinci dan seakan terpinggir dari arus pemikiran ijtihad semasa.

Untuk menjelaskan konsep ta'äbudiyyah dan sejauh mana kepentingannya dalam ijtihad, makalah ini terlebih dahulu menjelaskan impak fungsi akal dan ta' $\bar{l} \bar{l}$ dalam memahami nas syarak. Ia kemudiannya disusuli dengan perbahasan secara khusus terhadap pengertian konsep ta'äbudiyyah dalam perbincangan ilmu Usul Fiqh dan kesannya dalam pengkelasan hukum syarak. Seterusnya ia menjelaskan kepentingan konsep ta'äbudiyyah sebagai salah satu falsafah asas dalam memahami Syariat Islam khasnya dalam menangani isu-isu hukum semasa.

\section{Akal dan Ta'līl}

Dalam usaha memahami dan beramal dengan nas-nas syarak, secara amnya terdapat dua aliran utama di kalangan fuqaha. Pertama, golongan yang cenderung berpegang hanya pada zahir lafaz sahaja. Oleh itu, mereka menolak ta lìl nas-nas syarak, 
sebagaimana yang masyhur di kalangan ulama Zahiriyyah. Kedua, golongan jumhur ulama yang mendalami makna dan pengertian yang terkandung dalam sesuatu nas. ${ }^{1}$ Golongan ulama inilah yang banyak menggunakan prinsip ta 'līl al-ahkam al-shar 'iyyah dalam memahami nas.

Perkataan al-Ta'līl dalam perbahasan ilmu Usul Fiqh ia dirujuk kepada perkataan 'illah. Al-'illah dari sudut bahasa bererti suatu nama yang diberikan kepada sesuatu perkara yang kewujudannya akan menyebabkan berubahnya keadaan sesuatu kepada suatu keadaan yang lain. ${ }^{2}$ Contohnya, penyakit itu dikatakan suatu 'illah kerana ia merubah keadaan seseorang yang sihat menjadi sakit. ${ }^{3}$ Manakala dalam istilah ilmu Usul Fiqh, ${ }^{4}$ ia merujuk kepada suatu sifat atau keadaan yang jelas (zahir) yang mana pensyariatan hukumnya membawa kemaslahatan kepada manusia sama ada dalam bentuk mendatangkan manfaat atau menolak mudarat ${ }^{5}$.

Dari segi konsepnya, perkataan ta ' lil bolehlah dirujuk kepada usaha para ulama menggunakan ketajaman minda untuk memahami rasionaliti di sebalik pensyariatan hukum hakam syarak terutamanya di bidang muamalat. Ternyata sebahagian besarnya mempunyai rasioanaliti yang tertentu. Begitupun, sebahagian rasionaliti itu (hikmah) yang bersifat abstrak dan tidak boleh diukur dengan para meter tertentu menyebabkan ia tidak sesuai dijadikan paksi atau kausa hukum. Oleh itu, para ulama bersepakat mengatakan wajib mencari rasionaliti zahir, yang kerananya hukum syarak disyariatkan. ${ }^{6}$ Sebagai contoh, musafir adalah 'illah diharuskan menunaikan solat secara qasar.

1 Khalīfah Bā Bakr Hassan, Al-Ijtihād bi al-Ra'y fì Madrasat al-Hijāz alFiqhiyyah (Kaherah: Maktabat al-Zahrā' al-Hassan, 1997) 374.

2 Muḥammad bin Muḥammad al-Ghazālī, Al-Mustasfā min 'Ilm al-Ușūl al-Fiqh (Beirut: Dār Ihyā' al-Turath al- 'Arabī, 1997), 2-96.

3 'Alī Muhammad Sharīf al-Jarjānī, al-Ta'rîfầt (Kaherah: Dār al-Rayyān li alTurāth, 1978), 201.

4 Sha‘bān Muhammad Ismā‘̄il, Dirāsāt Hawl al-Qiyās wa al-Ijmā' (Kaherah: Maktabah al-Nahḍah al-Misriyyah, 1988), 164.

5 Sebenarnya ulama berbeza pendapat tentang hakikat 'illah. Al-Shātibī mempunyai persoektif yang tersendiri, di mana beliau menyamakan 'illah dengan maslahah dan hikmah al-tashrī. Ini dinyatakan sendiri oleh beliau dalam kitabnya al-Muwāfaqāt, 1-236.

6 'Abbās Husnī Muhammad, Perkembangan Fiqah Islam, terj. Mohd Asri Hashim (Kuala Terengganu: Percetakaan Yayasan Islam, 1996), 66. 
Keharusan menqasarkan solat akan diberikan kepada seseorang apabila ia bermusafir, sebaliknya bila ia tidak musafir maka keharusan menqasarkan solat itu tidak diberikan. Manakala unsur kemungkinan wujud kesukaran (mazannāt al-mashaqqah) adalah disebut sebagai hikmah.

Oleh itu, perkataan ta 'līl (proses pencarian 'illah) pula boleh diertikan sebagai suatu ijtihad rasional untuk mengesan, menerang dan mentafsirkan 'illah hukum hakam yang terkandung dalam nas syarak. Ia membuka ruang kepada sesuatu hukum yang sabit melalui nas untuk digunakan dalam masalah lain. Walaupun 'illah pada asalnya dibahaskan secara mendalam dalam memahami qiyas, namun perbincangan tentang permasalahan $t a ' l i l$ dikatakan telah berkembang dan seterusnya mendominasi lain-lain perbahasan tentang sumber-sumber perundangan Islam seperti $a l$ Istiḩsān dan al-Masālih al-Mursalah.' Oleh itu, ta 'līl bolehlah dikira sebagai induk kepada perkembangan ijtihad dalam Fiqh Islam. $^{8}$

Menyentuh hubungan antara peranan akal dan ta 'lìl dalam memahami nas syarak, Muhammad Fathī al-Duraynī ${ }^{9}$ menyimpulkan:

$$
\text { الأصل في النصوص التعليل فذلك دليل بين على معقولية النصوص القرآنية }
$$

Terjemahan: Asal pada nas-nas mempunyai 'illah, ia adalah bukti yang jelas terhadap kerasionalan nas-nas al-Qur'an.

Sememangnya al-Qur'an dan al-Hadith sering mengaitkan sesuatu hukum dengan 'illah tertentu. Dalam hal ini, Ibn Qayyīm ${ }^{10}$ telah membawakan banyak contoh dari kedua-duanya. Bahkan dalam Miftāh Dār al-Sa $\bar{a} d a h,{ }^{11}$ beliau menegaskan bahawa unsur ta 'lïl boleh dikesan lebih daripada seribu tempat bagi sesuatu hukum telah dinaskan berserta dengan illahnya sekali di dalam al-

7 Khalīfah Bā Bakr Hassan, al-Ijtihād bi al-Ra'y fì Madrasat al-Hijāz alFiqhiyyah, 371.

8 Perbahasan yang agak menarik dan mendalam dalam perkara ini bolehlah dirujuk kepada kita ta 'î̀l al-ahkam oleh al-Shalabī dan kitab al-ijtihād bi alRa'y fì Madrasah al-Hijāz al-fiqhiyyah oleh Khalifah Bā Bakr al-Ḥassan.

9 Muhammad Fatḥ̄ al-Durayn̄̄, Buhūth Muqaranah fì al-Fiqh al-Islāmī wa Ușūlih (Beirut: Muassasah al-Risālah, 1994), 29.

${ }^{10}$ Ibn Qayyim al-Jawziyyah, Miftāh Dār al-Sa'ādah wa Manthūr Wilāyat al- 'Ilm (Beirut: Dār al-Kutub al-Ilmiyyah Fanniyyah al-Muttahidah, t.t.), 2:196-200.

${ }^{11}$ Ibn Qayyim al-Jawziyyah, Miftāh Dār al-Sa ‘ādah wa Manthūr Wilāyat al-'Ilm, 2: 22 . 
Qur'an dan al-Sunnah. Selepas zaman Rasulullah SAW para sahabat telah meneruskan metode berta' $l \bar{l} l$ dalam berijtihad dan diikuti kemudiannya oleh para ulama. ${ }^{12}$

Bermula dengan usaha para ulama sejak dari zaman Rasulullah memahami nas melalui $t a$ ' $l \bar{l} l$, ternyata ilmu fiqh Islam telah berkembang secara pesat. Semua sumber hukum Islam yang berbentuk rasional seperti qiyās, istiḩsān, masālih mursalah dan sebagainya juga dikatakan berpunca dari pemahaman terhadap konsep ta 'lil hukum. ${ }^{13}$ Sebagai contoh:

i. Qiyās adalah proses untuk menyamakan hukum pada dua keadaan berdasarkan keduanya mempunyai kesatuan pada 'illah juz' ${ }^{1}{ }^{14}$

ii. Istihssān adalah suatu keadaan di mana terdapat dua 'illah juz' $\bar{\imath}$ boleh digunakan. Lalu diambil illah yang tampak dari segi zahirnya kurang kuat, tetapi mempunyai kesan yang lebih kuat berdasarkan bahawa ia lebih sesuai dengan 'illah kulli. ${ }^{15}$

iii. Masālih Murșalah melibatkan keadaan yang tidak mempunyai penyataan 'illahjuz' ' (tertentu) sama ada ia diterima atau ditolak oleh syarak. Oleh itu ia perlu dirujuk kepada 'illah kullī (merujuk kepada kemaslahatan umum). ${ }^{16}$

Pada dasarnya majoriti hukum syarak boleh dikesan 'illahnya sama ada secara dinaskan atau ditakhrijkan 'illahnya. Namun para mujtahid juga mengakui bahawa terdapat juga hukum syarak yang tidak dapat dipastikan 'illah hukumnya secara khusus. Ketika itu akal seseorang mujtahid akan berpada dan berhenti kepada apa yang disebutkan oleh syarak. Rahsia dan hikmahnya disifatkan ghayr ma'qul al-ma'nā. Fenomena ketidakmampuan akal untuk

${ }^{12}$ Aḥmad al-Raysūn̄̄, Naẓariyyyāt al-Maqāsid 'ind al-Imām al-Shātibī (Riyadh: al-Dār al-Ilmiyyah li al-Kitab al-Istāmī, 1992), 203.

13 Jād al-Haq 'Alī Jād al-Haq, al-Fiqh al-Islāmī Murūnatuh wa Tațawwaruh (Kaherah: Mujamma al-Buhūth al-Islāmiyyah,1989), 137.

${ }^{14}$ Iaitu illah yang biasa difahami dalam bab qiyās, seperti mabuk (menghilangkan akal yang merupakan 'illah bagi pengharaman arak) pada pengharaman arak.

15 Biasanya melibatkan kemaslahatan yang dibincangkan secara meluas dalam 'ilm Maqāsid.

${ }^{16}$ Wan Mohd Yusof Wan Chik, "Perkaedahan-perkaedahan Perundangan Islam: Sejarah, Pengkategorian, Fungsi, Kaitan dan Asas Pembentukan" (Tesis Sarjana, Fakulti Pengajian Islam, Universiti Kebangsaan Malaysia, 1999), 131. 
melakukan $\mathrm{ta}$ ' $\bar{l} l$ atau ketiadaan 'illah tertentu inilah yang disebut sebagai Ta'ābudiyyah. ${ }^{17}$

\section{Definisi $a l-T a ' a ̄ b u d i y y a h$}

Al-Ta'ābudiyyah merupakan kata terbitan bagi perkataan ta'abbada. Dari sudut bahasa, antara lain maksudnya adalah menjadikan sesuatu itu hamba, merendahkan diri, beribadah, ketaatan dan kepatuhan serta ditaklifkan ${ }^{18}$ Pada amnya para ahli ilmu Fiqh dan Usul Fiqh menggunakan istilah ta'ābudiyyah untuk menunjukkan dua ${ }^{19}$ pengertian:

i. Perbuatan-perbuatan yang berbentuk ibadah yang merujuk kepada makna istilah perkataan ibadah.

ii. Hukum hakam syarak yang tidak nampak 'illah ${ }^{20}$ pensyariatannya dimana kemampuan rasional akal manusia tidak dapat mengenalpasti hakikat dan rahsia disebalik pensyariatan sesuatu hukum (perkara). Ketaatan dan penderhakaan akan diberi balasan dalam bentuk pahala dan dosa di akhirat. Sebagai contoh jumlah rakaat solat. Kewajipan berpuasa di bulan Ramadhan, jumlah sebatan dalam had zina dan lain-lain lagi. ${ }^{21}$

Dalam bahasa Melayu, ia sering diterjemahkan sebagai pengabdian diri kepada Allah. Ternyata terjemahan ini adalah lebih merujuk kepada pengertian yang pertama dan agak sinonim dengan makna perkataan ubudiyyah. Manakala dalam konteks perbincangan ilmu Usul Fiqh, perkataan ta'äbudiyyah kebiasaannya merujuk kepada pengertian kedua. ${ }^{22}$

${ }^{17}$ Muhammad al-Ṭāhir Ibn 'Āshūr, Maqāsid al-Sharī'ah al-Islāmiyyah, ed. Muhammad Țāhir al-Misawī (t.tp.: al-Basā'ir li al-Intāj al-'Ilm, 1998), 162.

${ }^{18}$ Ibrāhīm Mustafā et.al, al-Mu jam al-Wasìt (Istanbul: Dār al-Da'wah, 1990), 2:2-579.

${ }^{19}$ Pada hemat penulis ada satu lagi pengertian kepada perkataan ini dalam kitabkitab perundangan Islam iaitu berpada dan berhenti kepada apa yang telah dihadkan maknanya oleh syarak.

${ }^{20}$ Selain perkataan 'illah, sesetengah sarjana menggunakan perkataan hikmah juga digunakan kepada perkara yang tidak dijangkaui oleh akal. Mungkin ini merujuk kepada permasalahan "al-tanawub bayna al-kalimāt." Hal ini boleh juga dilihat dalam kitab al-Muwāfaqāt

21 Qutub Muḥammad Sanu, Mưjam Muștalahāàt Ușūl al-Fiqh: Arabī-Inglizī (Damsyik: Dār al-Fikr, 2000), 137.

${ }^{22}$ Pengertian kedua inilah yang akan diperbahaskan dalam kertas kerja kecil ini. 
Perlu juga difahami bahawa illah-'illah dalam hukum berbentuk ta'äbudiyyah yang tidak dapat difahami oleh akal dan rasional manusia ialah 'illah khusus, walau bagaimana pun hikmah yang umum $^{23}$ di sebalik sesuatu hukum itu mungkin boleh dikesan. ${ }^{24}$ Menurut al-Shāṭib̄, pengesanan terhadap hikmat alhukm tidak menjejaskan sifat ta'äbudiyyah sesuatu hukum selagi mana 'illahnya yang khusus tidak dapat dijangkaui. Sebagai contoh permasalahan 'iddah. Walaupun hikmah umumnya dapat difahami iaitu membersihkan rahim dan mengelakkan percampuran air mani (keturunan), tetapi illah khususnya tidak dapat dipastikan. ${ }^{25}$ Maka dalam hal ini, masalah iddah tetap dianggap dalam kategori hukum ta'ābudiyyah .

\section{Hukum Hakam yang Bersifat $\mathrm{Ta}^{\top} a \bar{b}$ udiyyah}

Kajian terperinci terhadap nas-nas syarak menunjukkan bahawa hukum hakam dalam syariat Islam mengandungi 'illah-'illah yang merencanakan kemaslahatan kepada manusia. Namun, tidak semua 'illah tersebut dapat dijangkau oleh pemikiran manusia. Para fuqaha secara amnya membahagikan hukum berdasarkan prinsip ta 'līl al-ahkam kepada dua kategori. Pertama, disebut almu'allal iaitu yang dikenalpasti 'illahnya. Kedua, al-ta'abbudī iaitu tidak dikenalpasti 'illahnya. Namun begitu, para fuqaha yang mendalami permasalahan ta'lil secara mendalam, seolah-olah membahagikannya kepada tiga kategori.

a. Kategori hukum mempunyai 'illah. 'Illah hukum seperti ini diketahui samada kerana ia telah disebutkan oleh nas secara langsung atau boleh diistinbatkan dengan mudah. Contohnya, sifat mabuk sebagai 'illah pengharaman arak dan kemungkinan menimbulkan permusuhan dan persengketaan sebagai 'illah dalam kes meminang tunangan orang.

${ }^{23}$ Hikmah umum dalam hukum-hukum berbentuk ta 'abbudiyyah ini akan cuba dihuraikan di penghujung kertas kerja ini.

${ }^{24}$ Hikmah al-Hukm dalam perbincangan ilmu Usul Fiqh dan juga ilmu Maqāșid merujuk kepada sesuatu sifat atau keadaan yang timbul natijah dari pensyariatan sesuatu hukum. Sifat atau keadaan tersebut didapati menghasilkan kemaslahatan atau menghalang kemudaratan kepada manusia di dunia dan akhirat, 165.

${ }^{25}$ Abū Ishāq Ibrāhīm bin Mūsā al-Lakhmī al-Gharnāṭ̄i al-Mālikī al-Shātibī, alMuwāfaqāt fì Ușūl al-Sharī'ah, ed. Shaykh Ibrāhīm Ramaḍān (Beirut: Dār alMa'rifah, 1997), 2:2 -234. 
b. Kategori hukum tidak diketahui illahnya. Hukum hakam seperti ini dikenali sebagai hukum hakam ta'ābudiyyah. Contohnya, 'illah kenapa solat Zohor empat rakaat dan Subuh dua rakaat.

c. Kategori hukum yang berada di antara kedua-dua ketagori di atas. Iaitu hukum yang 'illahnya agak tersembunyi. Para fuqaha terpaksa bertungkus-lumus melakukan istinbat 'illah-'illahnya dan berselisih faham dalam menentukannya. Contoh, 'illah pengharaman ribā al-faḍl. ${ }^{26}$

Para ulama berselisih pendapat mengenai adakah hukum hakam syarak yang ditaklifkan kepada manusia pada asalnya bersifat ta'äbudiyyah atau mempunyai 'illah (mu'allalah). AlShāțibī memberikan pendapat yang lebih terperinci berdasarkan pemerhatian dan pengalamannya mengkaji hukum hakam syarak. Dalam pemerhatiannya, beliau mendapati bahawa terdapat perbezaan antara tabiat hukum ibadat dan hukum yang berkait dengan urusan hidup harian (al-adat). Beliau membuat kesimpulan yang amat menarik di dalam kitabnya al-Muwāfaqāt:

$$
\begin{aligned}
& \text { الأصل في العبادات بالنسبة إلى المكلف التعبد, دون الالتفات إلى المعاني, } \\
& \text { وأصل العادات الالتفات إلى المعاني }
\end{aligned}
$$

Terjemahan: Asal pada ibadah adalah al-ta'abbud, tanpa melihat kepada makna-makna. Manakala asal pada adat (urusan hidup seharian) adalah melihat kepada makna-makna (rahsia, hikmah atau kemaslahatan).

Penyataan beliau di atas tidak bermaksud bahawa tidak ada sebarang hikmah atau kemaslahatan yang terkandung di sebalik pensyariatan hukum hakam ibadat. Tetapi, yang diutamakan ialah konsep ketundukan kepada hukum hakam syarak. Manakala hikmah atau kemaslahatan di sebaliknya adalah dianggap sebagai sampingan yang tidak perlu dijadikan matlamat. Dalam hal adat pula masalah hikmah dan kemaslahatan hukum hakam syarak perlu dijadikan mekanisme pemantau yang bertindak mengiringi pensyariatan.

\footnotetext{
${ }^{26}$ Ibn 'Āshūr, Maqāṣid al-Sharī 'ah al-Islāmiyyah, 163.
} 


\section{A. Ta'ābudiyyah dalam Ibadah}

Hukum hakam yang berkaitan perkara ibadah umumnya bersifat ta 'äbudiyyah. Ini boleh dilihat secara jelas dalam permasalahan taharah, perbuatan, keadaan dan waktu solat, penggunaan air sebagai alat untuk bersuci, puasa dan haji. Dominasi elemen ta'ābudiyyah dalam ibadah tidaklah bermaksud para mujtahid gagal mengesan sebarang hikmat dan kemaslahatan padanya. Bahkan mereka mengakui dan mengesan hikmah dan kemaslahatan yang bersifat umum, paling asas sekurangnya ia bersifat ujian dan dugaan terhadap tahap ketundukan dan kepatuhan kepada Pencipta. Hikmah umum dalam solat yang bersifat mencegah seseorang dari berbuat buruk dan mengingati Allah jelas disebut dalam nas-nas. Namun, persoalan kenapa solat ditentukan dengan perbuatan dan bacaan tertentu secara khusus adalah suatu yang tidak dapat dihuraikan oleh akal manusia.

Begitu juga persoalan yang berkaitan dengan sebab ditaklifkan sesuatu ibadah dengan keadaan tertentu seperti kenapa solat Zohor dikaitkan dengan gelincir matahari dan kenapa dikaitkan kefarduan puasa dengan kehadiran bulan Ramadhan.

\section{B. Ta'ābudiyyah dalam Urusan Adat}

Pemerhatian yang mendalam ke atas hukum hakam syarak menunjukkan bahawa syariat Islam adalah bermatlamatkan kemaslahatan. Hal ini amat jelas dalam hal-ehwal kehidupan manusia. Hukum hakam syarak sentiasa berkiat dengan kemaslahatan. Oleh itu, apabila sesuatu perkara yang ditegah dalam keadaan yang tidak memberikan sebarang kemaslahatan, tetapi apabila ia mendatangkan kemaslahatan tertentu ia dibenarkan. Bahkan syarak sendiri banyak menyebut tentang 'illah-'illah hukum yang berkaitan dengan hal ehwal kehidupan manusia seharian.

Walaupun kebanyakan hukum hakam berkaitan urusan kehidupan harian dikatakan mempunyai 'illah, tetapi ada juga sebahagian kecil yang didapati termasuk dalam hukum hakam yang berbentuk ta'äbudiyyah. Dalam keadaan seperti ini, hendaklah dibataskan dan diserahkan pengertiannya kepada apa yang dinaskan, Contohnya kewajipan memberi mahar dalam perkahwinan, penentuan bahagian tertentu haiwan dalam penyembelihan, penentuan golongan dan kadar tertentu dalam 
pembahagian harta puaka, pengharaman babi, tempoh iddah dalam masalah perceraian dan kematian.

Di samping itu, permasalahan undang-undang jenayah yang berkaitan dengan hudud, ${ }^{27}$ secara dasarnya adalah berbentuk ta 'ábudiyyah. Begitu juga dalam masalah penetapan kadar kifarah, dan penetapan kadar bilangan sesuatu perkara seperti jumlah rakaat, jumlah sebatan, jumlah saksi dan sebagainya. ${ }^{28}$

\section{Kepentingan Prinsip al- Ta'ābudiyyah dalam Konteks Hukum Islam Semasa}

Secara mudahnya, hukum Islam semasa dan setempat ialah hukum yang difahami dari kitab Allah. Iaitu dengan mengambil kira realiti semasa dan setempat dengan menggunakan sepenuhnya kemampuan akal berdasarkan kaedah dan metodologi yang telah digariskan oleh para ulama terdahulu dalam kitab-kitab usul fiqh. Mahmood Zuhdi ${ }^{29}$ pernah menegaskan bahawa:

"Apa yang semasa dan setempat dalam konteks ini ialah kefahaman dan pentafsiran itu, bukan kitab atau nas alQur'an dan al-Sunnah yang berkenaan. Kerana nas kebenarannya adalah di luar pengaruh masa dan setempat. Ini kerana ia adalah bersifat muqaddas, mutlaq, syumul, 'alamī dan abadi, ${ }^{30}$ sedangkan kefahaman manusia sentiasa terdedah kepada perubahan oleh pelbagai sebab. Antaranya adalah unsur pendidikan, keilmuan, pencapaian kemajuan, realiti hidup dan sebagainya."

Sorotan kepada sejarah fiqh Islam menunjukkan ia telah mengalami pelbagai zaman. Bermula dengan penghayatan terhadap kalimat tauhid dan konsep 'ubudiyyah, terbukti syariat

${ }^{27}$ Ibn 'Āshūr mencadangkan kepada para fuqaha supaya lebih berhati-hati dalam menetapkan.

${ }^{28}$ Muḥammad Sulaymān 'Abd Allāh al-Ashqar, al-Wāọiḥ fì Ușūl al-Fiqh li alMubtādi'īn (Amman: Dār al-Nafā' is dan Dār al-Fath, 1992), 239.

${ }^{29}$ Mahmood Zuhdi, "Hukum Islam Semasa bagi Masyarakat Malaysia yang Membangun" dalam Abdul karim Ali, ed. Hukum Islam Semasa bagi Masyarakat Maysia yang Membangun (Kuala Lumpur: Akademi Pengajian Islam, Universiti Malaya. 1997), 4.

${ }^{30}$ Muqaddas ertinya sangat murni dan tidak mengandungi apa-apa cacat-cela. mutlaq bermaksud kebenarannya adalah mutlak iaitu tanpa syarat syumul merujuk kepada cakupannya yang lengkap dan komperehensif. 'Alamī menjelaskan kuatkuasanya universal dan abadi bermakna ia bersifat kekal selama-lamanya. 
Islam telah berjaya membina satu acuan dan wawasan kehidupan yang menggerakkan penganutnya membina tamadun yang tersendiri. Kekudusan nas-nas syarak yang bersifat memandu ternyata tidak sekali-kali menolak dinamika minda dan akal manusia dalam mencari ilmu pengetahuan. Bahkan ia menganjurkan penggunaannya semenjak penurunan wahyu pertama lagi. Rasulullah SAW dalam hayatnya sentiasa menggilap upaya dan potensi akal para sahabat untuk memahami nas-nas syarak agar ia boleh diimplementasikan dalam sebarang situasi dan realiti. Begitu juga didapati bahawa nas-nas syarak tidak bersifat diktator, menolak dan menghapuskan segala adat budaya yang ada. ${ }^{31}$ Bahkan, secara bijaksana ia meraikan, memperhalusi dan menyempurnakan segala kemaslahatan yang mampu tercapai oleh akal manusia. ${ }^{32}$

Usaha menjulang nas syarak, meraikan daya intelektual manusia dan memahami realiti semasa ini berlaku secara berterusan dari zaman sahabat, tābi 'ìn, tāabi'-tābi'inn, para imam mazhab, sehingggalah ke zaman fiqh berada di puncak kegemilangan. Pada saat itu, fiqh bukan sahaja bersifat semasa bahkan bertindak mendahului masa. Selepas itu, timbullah era kejumudan fiqh. Nas-nas syarak, akal dan situasi semasa tidak difungsikan secara sepatutnya. Maka ummah ditimpa saat kemunduran. Bukan tiada suara-suara yang cuba mengajak dibuat perubahan agar fungsi fiqh, nas-nas syarak, akal dan situasi dikembalikan. Tetapi suara-suara itu lenyap begitu saja. Maka kerangka tauhid dan binaan 'ubudiyyah menjadi terlalu lemah.

Zaman dan manusia telah banyak berubah. Usaha tokohtokoh reformis pada awal abad ke 20M telah serba sedikit merubah fenomena kebekuan fiqh. Pendapat yang mengatakan "pintu ijtihad telah tertutup" telahpun menjadi satu sejarah. Kini para ulama, sarjana mahupun ilmuwan Islam kelihatan telah, sedang dan akan bergerak untuk menjadikan fiqh sebagai sesuatu

${ }^{31}$ Syariat Islam telah meneruskan beberapa adat dan budaya arab sebelum Islam yang sesuai dengan kemaslahatan. Contohya dalam masalah diat, qasamah, perhimpunan pada hari "al- 'Urubah (jumaat) dan sebagainya.

${ }^{32}$ Hal ini dijelaskan oleh al-Shātibī bahawa pemikir-pemikir suatu bangsa mungkin boleh mengesan kemaslahatan-kemaslahatan yang berkait dengan urusan harian mereka, tetapi tidak boleh berbuat demikian dalam hal ibadah. Lihat Abū Ishāq Ibrāhim bin Mūsa al-Shātibī, al-Muwāfaqāt fì Ușūl alSharī'ah, 2:591. 
yang relevan dengan zaman. Mereka sesungguhnya berhadapan dengan satu tugas besar bagi menjaga kemurnian syarak dan membangunkan potensi ummah dalam realiti ketamadunan yang canggih. Bermacam-macam cubaan dari luar dan dalam timbul. Namun, antara dugaan yang paling besar mutaakhir ini, ialah kemunculamn aliran-aliran pemikiran "beredisi" baru. Akibatnya, fiqh yang pada suatu masa dikatakan kaku terikat dengan hasilan fiqh terdahulu kini sedang berhadapan dengan kemelut baru yang lebih tragis, iaitu kecenderungan menggunakan akal secara berlebihan. $^{33}$

Fenomena ini sebenarnya adalah natijah kepada perasaan al'ajz wa al-kasl serta al-jubn wa al-bukhl. Pasrah kepada tekanan peradaban terkini atas alasan darurat dan rukhsah tanpa merintis kembali kepada kebiasaan dan al-azimah sebagai jalan. Kelahiran aliran-aliran "Islam Modernis, Islam Neo-Modernis, Islam Amerika, Anti Hadis, Islam Kontemporari, Islam Liberal, ${ }^{34}$ dan pelbagai "Islam-Islam" yang bakal menyusuri. Mungkinkah usaha para orientalis sebelum ini telah diwarisi oleh sebahagian kalangan umat Islam sendiri? Sebagai contoh, nas-nas syarak cuba ditanggapi secara bebas tanpa menghiraukan aspek kekudusannya. Bahkan dalam banyak aspek, kekudusan itu diberikan kepada situasi dan realiti semasa atas alasan kemaslahatan dan keterdesakan. Hukum hakam bukan lagi cuba difahami dan diamalkan dalam kerangka dan konsep pengabdian ('ubudiyyah) kepada Allah, tetapi kerana mendambakan kemaslahatan dan hikmah-hikmah rasional yang disangkakan. Mungkin suatu yang lebih tragis seandainya hukum hakam itu difahami untuk mencari alasan untuk tidak diamalkan. Dalam lain perkataan, semuanya mahu diletakkan nilai logik tanpa menghiraukan keterbatasan cakupan akal dalam memahami apa yang disebut ghayr ma 'qül al-

${ }^{33}$ Pada hemat penulis, syariat boleh diumpamakan air tabiatnya. Sebagaimana yang dikatakan dalam sebuah syair:

$$
\text { إني رأيت وقوف الماء يفسده إن سال طاب وإن لم يجر لم يطب }
$$

dan penulis merasakan sekarang ini perlu diperjelaskan juga bahawa hakikat air apabila mendidih akan menjadi wap:

$$
\text { وإني ادركت أن غليانه يذهبه في المواء يطير ويتنشر يكاد يغيب }
$$

${ }^{34}$ Abdul Karim Ali dan Mohammad Zaidi Abdul Rahman, "Hukum Islam Semasa: Analisa Terhadap Pendekatan Golongan Modernis" dalam Shofian Ahmad ed. (Prosiding, Seminar Kebangsaan Fiqh Semasa, Jabatan Syariah, Fakulti Pengajian Islam, UKM, Bangi, 2003), 387. 
ma 'nā. Bahkan, hukum hakam yang berbentuk ta 'ābudiyyah inilah yang sering menjadi sasaran polemik mereka. Bagi mereka, tidak ada sesuatu pun yang bertaraf ta'äbudiyyah. Bahkan, semuanya boleh diakali. Justeru, apakah perbezaan golongan ini dengan kumpulan-kumpulan ajaran sesat yang meninggalkan taklif zahir atas dakwaan sudah mencapai maqam hakikat?

Atas alasan itu, para sarjana Islam yang insaf, perlu mengembalikan ijtihad dalam persoalan hukum semasa kepada landasan yang sepatutnya lā Ifrăt wa lā Tafriț. ${ }^{35}$ Andai pada zaman kejumudan fiqh para sarjana yang insaf bertungkus lumus mengenengahkan pentingnya konsep meraikan kemaslahatan dan ilmu maqasid dalam berijtihad, maka dirasakan hari ini perlu ada sarjana-sarjana yang memperlihatkan kepentingan konsep "ta'äbudiyyah" dalam syariat Islam dalam memahami permasalahan hukum dan realiti semasa. Berdasarkan kepada pemerhatian terhadap sebahagian permasalahan cabang fiqh dan beberapa kajian tentang permasalahan ta'äbudiyyah, didapati prinsip ta'ábudiyyah mempunyai peranan yang amat penting dalam syariat Islam. Antara kepentingan dan hikmah disebalik pensyariatan hukum hakam ta'ābudiyyah adalah seperti berikut.

\section{a) Konsep al-ibtila', dalam hukum hakam yang bersifat al- ta $^{`} \bar{a}$ budiyyah ${ }^{36}$}

Hikmah utama dalam pensyariatan hukum hakam yang bersifat alta 'äbudiyyah adalah sebagai suatu bentuk ujian terhadap tahap pengabdian diri dan ketaatan mereka kepada Maha Pencipta. Hal ini telah ditegaskan oleh al-Shātibī. ${ }^{37}$

$$
\begin{aligned}
& \text { وإنما فهمنا من حكمة التعبد العامة الإنقياد لأوامر الله تعالى وإفراده بالخضوع كالخع } \\
& \text { والتعظيم لجلاله والتوجه إليه..... بل كنا نؤمر بمجرد التعظيم }
\end{aligned}
$$

Terjemahan: Sesungguhnya apa yang kami fahami tentang hikmah al-ta'ābudiyyah secara am adalah satu bentuk ketundukan kepada perintah Allah, mengesakan dengan cara mematuhi, membesarkan kemuliaannya dan berserah

\footnotetext{
${ }^{35}$ Maksudnya tidak beku dan tidak terperwap.

${ }^{36}$ Unsur ini amat wujud terutamanya dalam hukum-hukum hukum-hukum alta'abbudiyyat yang berbentuk ibadah.

${ }^{37}$ Abū Ishāq Ibrāhīm bin Mūsā al-Lakhmī al-Gharnātī al-Mālikī al-Shāțib̄ị, alMuwāfaqāt fì Usūl al-Sharī'ah, 586.
} 
kepadaNya.. Bahkan kita diperintahkan hanya semata-mata untuk membesarkan (perintahNya).

Al-Ghazālīi ${ }^{38}$ menghuraikan perkara ini secara terperinci ketika menerangkan tentang rahsia di sebalik melontar jamrah dalam ibadat haji. Menurut beliau, ada sebahagian amalan yang ditaklifkan kepada manusia tidak dicenderungi oleh naluri dan jiwa manusia. Ini kerana hikmah dan kemaslahatan di sebalik tugasan tersebut gagal difahami oleh akal. Sebagai contoh; melontar jamrah dengan batu dan berulang alik antara Safa dan Marwah. Sebenarnya amalan-amalan dalam kategori inilah yang akan menunjukkan kesempurnaan pengabdian diri seseorang kepada Pencipta. Ini kerana apabila seseorang melakukan sesuatu perbuatan dalam kategori ini, maka perbuatannya hanyalah bermotifkan untuk mematuhi perintah Syarak bukannya kerana kecenderungan dan naluri diri untuk mencari kemaslahatankemaslahatan yang lain. Sebaliknya, kalau ia memahami kandungan hikmah dan kemaslahatan (dunia) di sebalik sesuatu perbuatan maka tahap kesempurnaan pengabdian diri tidaklah teruji. Kerana dorongan seseorang itu mentaati suruhan syarak mungkin bukanlah semata-mata untuk mentaatiNya tetapi kerana tujuan-tujuan yang lain. ${ }^{39}$ Al-Ghazālī turut menegaskan bahawa hukum hakam ta'ābudiyyah jenis inilah yang paling berkesan dalam pembersihan jiwa.

Mungkin kerana itulah sesetengah ulamak menamakannya sebagai ibadah mahdah ${ }^{40}$ (ibadah murni). Kemurniannya dirujuk kepada ia adalah suatu ibadah yang tidak diketahui illahnya. Akal manusia tidak dapat mencapai illah pensyariatannya. Alasan disebalik disyariatkannya diserah pada Allah. Yang paling penting ia suatu suruhan Allah dan manusia melakukannya dengan setulus hati, hanya untuk Allah.

\footnotetext{
${ }^{38}$ Muḥammad bin Muḥammad al-Ghazālī, Ihyā' 'Ulūm al-Dīn (Beirut: Dār alKutub al-'Ilmiyyah, 1998), 1:1-250.

${ }^{39}$ Perkara yang hampir sama juga telah dijelaskan oleh 'Izz al-Dīn ibn 'Abd alSalam dan hal ini telah dihuraikan secara lebih sistematik oleh al-Shātibī .

${ }^{40}$ Boleh dijadikan ibadah sebagai ibadah semata-mata.
} 


\section{b) Al-Ta'ābudiyyah bukti keterbatasan kemampuan akal manusia}

Pensyariatan hukum-hukum yang berbentuk ta'ābudiyyah juga menunjukkan keterbatasan akal manusia. Dalam banyak keadaan, manusia boleh memahami hal ehwal yang berkaitan dengan urusan seharian melalui akal. Bahkan, kewujudan tanda berakal dikira antara syarat asas dalam taklif. Namun, dalam masalah hukum hakam ta'ābudiyyah, mereka perlu berpada dengan ketetapan syarak kerana penggunaan akal biasanya akan menyebabkan mereka terseleweng dari jalan yang benar. Inilah yang pernah berlaku kepada syariat-syariat yang lalu. Hal ini membuktikan bahawa kemampuan akal tidak boleh digunakan secara bersendirian, bebas dari panduan syarak. ${ }^{41}$

\section{c) Al-Ta'äbudiyyah sebagai ketetapan bentuk kemaslahatan bersama untuk masyarakat}

Manusia walaupun dilahirkan dalam fitrah yang suci, tetapi ia tidak dapat lari dari dipengaruhi oleh situasi kehidupan dan pengalaman yang berbeza-beza. Maka timbullah perbezaan kecenderungan, kemaslahatan dan kepentingan dalam kehidupan. Selepas itu lahirlah pertelingkahan dan permusuhan. Untuk itu, konsep ta'abbudiyyat mempunyai peranan penting sebagai suatu ketetapan "standard" kemaslahatan bersama. ${ }^{42}$ Ini bermaksud pengertian makna (hikmah dan kemaslahatan) disebalik hukum hakam yang bersifat ta'ábudiyyah dalam urusan seharian manusia dan sebahagian ibadah adalah bertujuan menetapkan suatu standard kemaslahatan yang menyatukan individu-individu dalam sesuatu komuniti. Mungkin atas dasar ini, didapati kebanyakan hukum ta'ābudiyyah adalah bersifat $q a t^{i+43}$ yang disepakati. Ia seolah-olah menjadi satu asas penyatuan dan penyeragaman pemikiran dan tingkah laku untuk sesuatu ummah. Sesuatu ummah boleh dikatakan tidak wujud kalau di antara mereka tidak ada sebarang dasar dan ciri-ciri tertentu yang menyatukan individu-

\footnotetext{
${ }^{41}$ Al-Shātibī, Al-Muwāfaqāt fì Usūl al-Sharī'ah, 2:589.

${ }^{42}$ Al-Shātibī, Al-Muwāfaqūt fì Usūl al-Sharī'ah, 2:595.

${ }^{43}$ Pada hemat penulis, kebanyakan hukum-hukum bersifat ta 'abbudiyyat bersifat qat 't. Oleh itu, wujudnya khilaf dalam sesuatu permasalahan biasanya menandakan ia adalah bersiadt mu'allalah. Pendapat ini walaubagaimana pun masih sebagai hipotesis awal.
} 
individunya. Apatah lagi kalau sesuatu ummah itu didirikan atas dasar akidah (ideologi), bukan atas dasar sempadan mahupun bangsa. ${ }^{44}$

Al-Shātibī, ${ }^{45}$ mengatakan bahawa jika penetapan bentukbentuk kemaslahatan diserahkan bulat-bulat kepada kehendak masyarakat dan pandangan mereka, maka ia mungkin akan terus berubah-ubah (secara evolusi) dengan tidak terkawal. Dalam keadaan sebegitu, sukar sekali untuk merujuknya kembali kepada dalil-dalil syarak. ${ }^{46}$ Penetapan hukum dan kemaslahatan dalam hal ini lebih mudah dan berkesan dalam mendisiplin dan menetapkan tatacara kehidupan bermasyarakat. Oleh itu, syarak telah menetapkan dalam had jenayah kadar-kadar dan sebab-sebab tertentu yang tidak boleh dilangkaui seperti 80 sebatan dalam kes qazaf, 100 sebatan serta pemulauan setahun dalam kes penzina yang belum berkahwin dan sebagainya.

\section{d) al-Ta'ābudiyyah: Sebagai benteng keutuhan Syariah}

Memang tidak dapat dinafikan bahawa, fleksibeliti (murūnah) adalah antara faktor kekuatan Syariat Islam untuk terus berkembang dan kekal relevan sepanjang zaman. Namun, unsur tetap (thabat) mempunyai keistimewaan yang tersendiri dalam memelihara keaslian dan kemurnian dasar-dasar syarak. Oleh itu didapati unsur tetap ini amat berkaitan dengan hukum hakam yang bersifat al-ta'äbudiyyah. ${ }^{47}$ Ini boleh dilihat dalam permasalahan ibadah $^{48}$ dan hal ehwal kekeluargaan. ${ }^{49}$ Maka hukum hakam seperti ini pada prinsipnya tidak berubah walaupun tempat, masa dan keadaan berubah. Seandainya ia berubah maka ummah akan kehilangan identiti. Lain pula halnya dengan permasalahan

${ }^{44}$ Yūsuf al-Qaraḍāwī, Sharī'at al-Islām: Sālihah li al-Tatbiq fì Kullī Zamān wa Makān (Kuala Lumpur: Fajar Ulung Sdn. Bhd. 1997), 106.

${ }^{45}$ Al-Shāțib̄î, Al-Muwāfaqāt fì Usūl al-Sharī'ah, 2:493.

${ }^{46}$ Mungkin inilah yang berlaku dalam sejarah perundangan barat undang-undang terus berevolusi mengikut kehendak dan hawa nafsu masyarakat. Contohnya masalah homoseksual dan petkahwinan sejenis

${ }^{47}$ Sa'īd Muḥammad Buharawah, Al-Bu'd al-Zamānī wa al-Makānī wa 'Athāruhā fì al-Ta'āmmul ma'a al-Nāṣ al-Shar 'î, 118.

48 Ibadat seperi solat, zakat, puasa dan haji merupakan sesuatu yang tetap dan tidak berubah disebabkan perubahan zaman dan tempat. Dalam mana-mana keadaan sekalipun, ia tidak menerima penambahan atau pengurangan.

${ }^{49}$ Seperti permasalahan kewajiban mahar kahwin, iddah, wanita-wanita yang haram dikahwini, kadar harta pesaka dsan sebagainya. 
berkaitan dengan urusan kehidupan seharian terutama dalam masalah muamalat dan jenayah. Ia lebih bersifat fleksibel sesuai dengan tuntutan keadaan dan zaman. ${ }^{50}$ Oleh itu, didapati hukum hakam dalam kategori ini lebih bersifat mu'allalah.

\section{e) Al-Ta'äbudiyyah menunjukkan kepentingan $a l-w a s \bar{a} ' i l^{51}$}

Antara objektif syariat Islam adalah untuk menjaga fitrah dan kemaslahatan manusia. Ia tidak mencanggahinya sama sekali. Bahkan demi menjamin tercapainya kemaslahatan syarak, syarak telah mensyariakan wasā'il yang paing baik dan berkesan. Ini kerana wasā'il amat penting demi mencapai matlamat-matlamat syarak. $^{52}$

Umumnya, wasā'il dalam hukum hakam syarak bersifat fleksibel. Walau bagaimanapun tinjauan kepada hukum hakam yang bersifat ta'abbudiyyat menunjukkan wasā'ilnya bersifat tetap. Jadi aspek yang dipentingkan dalam hukum hakam berbentuk al-ta'äbudiyyah adalah berpegang kepada bentuk wasā'il yang ditetapkan oleh syarak. Secara falsafahnya, ini boleh dilihat dalam kisah penyembelihan Nabi Ismail a.s. Perkara yang ditaklifkan adalah wasă'il bukannya hasilan suruhan yang zahir. Hasilnya, ${ }^{53}$ hikmah atau matlamat sesuatu taklif tanpa melalui wasā'il yang ditetapkan oleh syarak, tidak akan melepaskan seseorang mukallaf dari taklif. ${ }^{54}$ Ini kerana syarak menganggap sesuatu itu sahih kalau ia dibuat berdasarkan ketetapan syarak. Sebaliknya jika wasa'il berlaku dengan sempurna tetapi hikmatnya tidak terhasil, maka amalan tersebut dianggap sah

${ }^{50}$ Ibn 'Āshūr, Maqāsid al-Sharī'ah al-Islāmiyyah (t.tp.: al-Basāir li al-Intāj al'Ilm 1998), 166 dan 167.

${ }^{51}$ Al-wasā'il bermaksud; mekanisme yang ditetapkan untuk mencapai matlamat pensyariatan sesuatu hukum.

52 Mahirah Sara Farid, "Al-Ta'dīb fì al-Fiqh al-Islāmī: al-Zawjah wa al-Awlād wa al-Talāmiz Namuzajan" (Disertasi sarjana, International Islamic Universiti Malaysia, 2005), 130.

${ }^{53}$ Dalam banyak keadaan, terhasilnya matlamat atau hikmat tanpa melalui wasa'il yang ditetapkan oleh syarak, adalah satu dakwaan palsu

${ }^{54}$ Jika ia adalah sesuatu yang wajib. Contohnya, seseorang yang mendakwa tidak perlu solat kerana hatinya tetap mengingati Allah walaupun tidak solat atau kerana dirinya sudah tercegah dari melakukan munkar walaupun dia tidak solat. 
dengan makna sudah terlepas dari dosa meninggalkannya walaupun kualiti amalan adalah rendah. ${ }^{55}$

\section{Penutup}

Dari huraian di atas, diharapkan telah menggambarkan kepentingan konsep al-ta'ābudiyyah dalam Islam. Dalam usaha menghidupkan budaya berijtihad demi menyelesaikan permasalhan ummah, persoalan hukum Islam semasa adalah suatu tuntutan yang amat diperlukan. Sebarang penafian terhadap kepentingan hukum Islam semasa sebenarnya adalah suatu bentuk "escapisme" dari realiti peradaban masakini. Ia pasti akan merugikan ummah. Rasululllah SAW sendiri tidak pernah mengajar ummah sikap mengalah kepada keadaan dan lari dari realiti. Namun begitu, aliran kesemasaan hukum tidak seharusnya dijadikan alasan atau dibiarkan menjadi ruang untuk digugat nilai keabadian dalam syariat Islam. Apatah lagi masyarakat Islam kini berhadapan dengan kebanjiran pemikiran yang cuba melonggarliberalkan semua urusan dalam beragama. Fenomena yang sebenarnya berpunca dari fenomena al-tab iyyah al-thaqafiyyah ${ }^{56}$ yang pernah disabdakan oleh Rasulullah sebagai ghalabat aldayn $^{57}$ dan qahr al-rija." ${ }^{, 58}$

Dalam hal ini sebarang kecuaian atau kesengajaan untuk tidak mengambil kira aspek al-ta'ábudiyyah dalam ijtihad hukum Islam semasa, akan menyebabkan ijtihad dan fiqh hukum Islam semasa kehilangan tautan dengan nas-nas syarak.

\section{Bibliografi}

Abdul Karim Ali dan Mohammad Zaidi Abdul Rahman. "Hukum Islam Semasa: Analisa Terhadap Pendekatan Golongan Modernis" dalam Shofian Ahmad. Prosiding, Seminar Kebangsaan Fiqh Semasa, Jabatan Syariah, Fakulti Pengajian Islam, UKM, Bangi, 2003.

\footnotetext{
${ }^{55}$ Hikmah ini jelas berlaku terutamanya dalam masalah ibadah.

${ }^{56}$ Mengikut telunjuk peradaban orang lain

${ }^{57}$ Dikuasai oleh hutang atau mengikut telunjuk orang lain dalam berekonomi lantaran buday berhutang

${ }^{58}$ Dikuasai oleh orang lain dalam membuat keputusan. Mungkin kerana kekuasaan politik dan sebagainya.
} 
Al-Ashqar, Muḥammad Sulaymān 'Abd Allāh. Al-Wāẹih fì Ușūl al-Fiqh li al-Mubtādi 'ìn. Amman: Dār al-Nafâ' is \& Dār al-Fath, 1992.

Al-Duraynī, Muḥammad Fatḥ̄. Buhūth Muqāranah fì al-Fiqh alIslāmī wa Ușūlih. Beirut: Muassasah al-Risālah, 1994.

Al-Jawziyyah, Ibn Qayyim. Miftāh Dār al-Sa 'ādah wa Manthūr Wilāyat al-'Ilm. Beirūt: Dār al-Kutub al-'Ilmiyyah Fanniyyah al-Muttahidah, t.t.

Al-Ghazālī, Muḥammad bin Muḥammad. Al-Mustasfā min 'Ilm alUșūl al-Fiqh. Beirut: Dār Ihyā' al-Turath al- 'Arabī, 1997.

al-'Ilmiyyah, 1998.

Al-Jarjān̄̄, 'Alī Muhammad Sharīf. Al-Ta 'rīfāt. Kaherah: Dār alRayyān li al-Turāth, 1978.

Al-Raysūn̄̄, Aḥmad. Naẓariyyyāt al-Maqāsid 'ind al-Imām alShātibī. Riyadh: al-Dār al-'Ilmiyyah li al-Kitab al-Islāmī, 1992.

Al-Qaraḍāwī, Yūsuf. Shar̄̄'at al-Islām: Sālihah li al-Tatbiq fì Kullì Zamān wa Makān. Kuala Lumpur: Fajar Ulung Sdn. Bhd. 1997.

Al-Shāṭibī, Abū Ishāq Ibrāhīm bin Mūsā al-Lakhmī al-Gharnāṭī alMālikī. Al-Muwāfaqāt fì Ușūl al-Sharī'ah, ed. Shaykh Ibrāhīm Ramaḍān. Beirut: Dār al-Ma'rifah, 1997.

'Abbās Husn̄̄ Muḥammad. Perkembangan Fiqah Islam, terj. Mohd Asri Hashim. Kuala Terengganu: Percetakaan Yayasan Islam, 1996.

Ismā'̄il, Sha'bān Muḥammad. Dirāsāt Hawl al-Qiyās wa al-Ijmāa . Kaherah: Maktabah al-Nahḍah al-Misriyyah, 1988.

Ibn 'Āshūr, Muḥammad al-Țāhir. Maqāsid al-Sharī'ah alIslāmiyyah, ed. Muhammad Ṭāhir al-Misawī. T.tp.: al-Basā'ir li al-Intāj al-'Ilm, 1998.

Ibrāhīm Mustafā et.al. Al-Mu jam al-Wasìt. Istanbul: Dār al$\mathrm{Da}^{6}$ wah, 1990.

Jād al-Ḥaq, Jād al-Ḥaq 'Alī. Al-Fiqh al-Islāmī Murūnatuh wa Tațawwaruh. Kaherah: Mujamma' al-Buhūth al-Islāmiyyah, 1989.

Khalīfah Bā Bakr Hassan. Al-Ijtihād bi al-Ra'y fì Madrasāt alHijāz al-Fiqhiyyah. Kaherah: Maktabat al-Zahrā' al-Ḥassan, 1997. 
Mahirah Sara Fari. "Al-Ta'dīb fĩ al-Fiqh al-Islāmī: al-Zawjah wa al-Awlād wa al-Talāmiz Namuzajan." Disertasi sarjana, International Islamic Universiti Malaysia, 2005.

Mahmood Zuhdi. "Hukum Islam Semasa bagi Masyarakat Malaysia yang Membangun" dalam Abdul karim Ali, ed. Hukum Islam Semasa bagi Masyarakat Maysia yang Membangun. Kuala Lumpur: Akademi Pengajian Islam, Universiti Malaya. 1997.

Qutub Muḥammad Sanu. Mu'jam Mușțalahāt Ușūl al-Fiqh: 'Arabì-Inglizī. Damsyik: Dār al-Fikr, 2000.

Wan Mohd Yusof Wan Chik. "Perkaedahan-perkaedahan Perundangan Islam: Sejarah, Pengkategorian, Fungsi, Kaitan dan Asas Pembentukan." Tesis Sarjana, Fakulti Pengajian Islam, Universiti Kebangsaan Malaysia, 1999. 